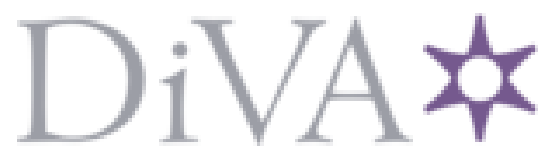

http://www.diva-portal.org

\title{
Postprint
}

This is the accepted version of a paper published in . This paper has been peer-reviewed but does not include the final publisher proof-corrections or journal pagination.

Citation for the original published paper (version of record):

Lööf, H., Johansson, B. (2014)

R\&D Strategy, Metropolitan Externalities and Productivity: Evidence from sweden.

, 21(2): 142-154

http://dx.doi.org/10.1080/13662716.2014.896600

Access to the published version may require subscription.

N.B. When citing this work, cite the original published paper.

Permanent link to this version:

http://urn.kb.se/resolve?urn=urn:nbn:se:kth:diva-144578 
This article was downloaded by: [Kungliga Tekniska Hogskola]

On: 24 April 2014, At: 23:11

Publisher: Routledge

Informa Ltd Registered in England and Wales Registered Number: 1072954 Registered

office: Mortimer House, 37-41 Mortimer Street, London W1T 3J H, UK

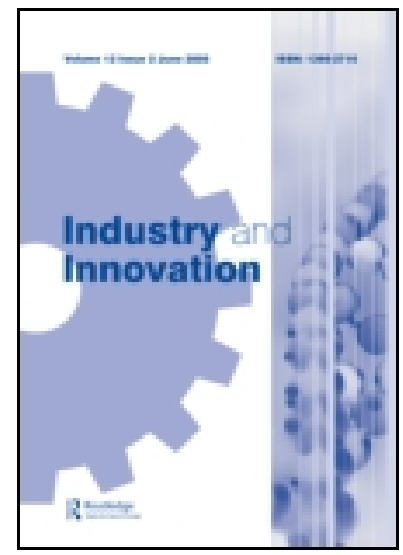

\title{
Industry and Innovation
}

Publication details, including instructions for authors and

subscription information:

http:// www.tandfonline.com/loi/ ciai20

\section{R\&D Strategy, Metropolitan Externalities and Productivity: Evidence from Sweden}

\author{
Hans Lööf ${ }^{a} \&$ Börje J ohansson ${ }^{\text {bcd }}$ \\ ${ }^{a}$ Royal Institute of Technology, Centre of Excellence for Science \\ and Innovation Studies, Stockholm, Sweden \\ b J onkoping International Business School, J önköping, Sweden \\ ${ }^{c}$ Centre of Excellence for Science and Innovation Studies, \\ Stockholm, Sweden \\ ${ }^{d}$ CIRCLE, Lund University, Lund, Sweden \\ Published online: 25 Mar 2014.
}

To cite this article: Hans Lööf \& Börje J ohansson (2014) R\&D Strategy, Metropolitan Externalities and Productivity: Evidence from Sweden, Industry and Innovation, 21:2, 141-154, DOI:

10.1080/ 13662716.2014.896600

To link to this article: http:// dx. doi.org/ 10.1080/ 13662716.2014.896600

\section{PLEASE SCROLL DOWN FOR ARTICLE}

Taylor \& Francis makes every effort to ensure the accuracy of all the information (the "Content") contained in the publications on our platform. However, Taylor \& Francis, our agents, and our licensors make no representations or warranties whatsoever as to the accuracy, completeness, or suitability for any purpose of the Content. Any opinions and views expressed in this publication are the opinions and views of the authors, and are not the views of or endorsed by Taylor \& Francis. The accuracy of the Content should not be relied upon and should be independently verified with primary sources of information. Taylor and Francis shall not be liable for any losses, actions, claims, proceedings, demands, costs, expenses, damages, and other liabilities whatsoever or howsoever caused arising directly or indirectly in connection with, in relation to or arising out of the use of the Content.

This article may be used for research, teaching, and private study purposes. Any substantial or systematic reproduction, redistribution, reselling, loan, sub-licensing, systematic supply, or distribution in any form to anyone is expressly forbidden. Terms \& 
Conditions of access and use can be found at http://www.tandfonline.com/page/termsand-conditions 


\title{
R\&D Strategy, Metropolitan Externalities and Productivity: Evidence from Sweden
}

\author{
HANS LÖÖF* \& BÖRJE JOHANSSON**,+,†† \\ ${ }^{*}$ Royal Institute of Technology, Centre of Excellence for Science and Innovation Studies, Stockholm, Sweden, \\ **Jonkoping International Business School, Jönköping, Sweden, ${ }^{\dagger}$ Centre of Excellence for Science and Innovation \\ Studies, Stockholm, Sweden, ${ }^{\dagger}$ CIRCLE, Lund University, Lund, Sweden
}

\begin{abstract}
This paper studies the influence of metropolitan externalities on productivity for different types of long-run R\&D engagement based on information from the Community Innovation Survey. We apply a dynamic general method of moments model to a panel of manufacturing and service firms with differentlocations in Sweden, classified as a metropolitan region, the largest metropolitan region, a metropolitan city, the largest metropolitan city and a nonmetropolitan area. This analysis generates three distinct results. First, the productivity premium associated with persistent $R \& D$ is close to 8 per cent in nonmetro locations and about 14 per cent in the largest city. Second, a firm without any R\&D engagement does not benefit at all from the external milieu in metro areas. Third, no productivity premium is associated with occasional $R \& D$ effort regardless of the firm's location.
\end{abstract}

KEY WORDS: R\&D, innovation strategy, productivity, metropolitan, externalities

JEL Classification: C23, O31, O32

\section{Introduction}

It is well established that business performance is affected by externalities, with external effects including a negative knowledge stealing effect and a positive spillover effect. For the typical firm, the latter effect tends to dominate. Bloom et al. (2013) suggest that the social rate of return for $R \& D$ is more than 30 percentage points above the private rate of return. Several authors find that spillovers increase with density and decline with distance. Using income as a proxy for the spillover effect, Glaeser and Mare (2001) estimate that the elasticity with respect to city size in the USA is within the range of 0.04-0.08. In their literature survey, Klaesson et al. (2014) report an elasticity of about 0.02 in studies similar to the one by Glaeser and Mare.

Correspondence Address: Hans Lööf, Centre of Excellence for Science and Innovation Studies, Royal Institute of Technology, Lindstedtsvägen 30, 100 44, Stockholm, Sweden. Tel.: +468790 80 12. Email: hans.loof@indek.kth.se 
In contrast to the large number of studies attempting to calculate the economic value of externalities, few studies have addressed the question of how potential spillover effects differ within and across geographical areas when these effects are recorded for firms with different internal characteristics. Since two seminal papers by Cohen and Levinthal (1989, 1990), some researchers have focused on how firms' innovative and absorptive capacity affect firm performance, but little attention has been devoted to understanding how firm performance differs when the same type of innovation strategy is applied by firms in different types of regions or how firm performance varies as different types of innovation strategies are applied in the same type of location. The present research attempts to fill this gap.

This paper contributes to the literature by examining the importance of local and regional environments for firms that employ one of the following three categories of innovation strategy: no R\&D effort, occasional R\&D effort and persistent R\&D effort. For each of these three categories, we assess the importance of firm location, classified into the following five types: a metropolitan region, the largest metropolitan region, a metropolitan city, the largest metropolitan city and a nonmetropolitan area. To reveal how different combinations of strategy and location affect firm performance, we use observations from the Community Innovation Survey (CIS) of Swedish manufacturing and service firms spanning from 2002 to 2004 and combine that information with register data for the observed CIS firms over the 2001-2006 period.

The regression analysis provides strong evidence that the benefit of urban density increases with the permanence of a firm's innovation effort and that this effect is quite sizable. Compared with non-R\&D firms in nonmetropolitan areas as the reference group, the productivity premium of being located in the largest metro city is not statistically different from 0 per cent for both non-R\&D firms and firms with just temporary R\&D engagements, and 14 per cent for firms that are persistently engaged in R\&D activities. The regression controls for lagged productivity during the three previous years, ordinary labor, skilled labor, physical capital, ownership, sector and fixed effects.

The remainder of the paper is organized as follows. Section 2 provides a review of the relevant literature. The data are presented in section 3. Econometrics methods are discussed in Section 4, and the results are reported in section 5 . Section 6 summarizes the conclusions of this work.

\section{Background from the Literature}

There is substantial evidence that knowledge sources inside an urban region generate spillovers that affect the performance outcomes of firms located in the region, although the precise mechanism and size of this effect remain open questions (Greenstone et al., 2010). The literature suggests three factors that lead friction costs of knowledge diffusion to increase as communication distance increases: knowledge is complex (Beckmann, 2000), tacit (Polanyi, 1966) and spatially sticky (von Hippel, 1994). Fujita and Thisse (2002) show that the likelihood of knowledge contacts decreases with the distance between the origin and destination, and this is interpreted as a reason for spatial concentration.

A firm can influence its knowledge flow environment by establishing formal and informal links to other actors such as its input suppliers, its customers, universities and other knowledge providers. Network development of this kind is less costly to carry out inside an urban region, and the advantage of a metropolitan region lies in the fact that the number of 
potential contacts is much larger and more diversified than elsewhere (Simmie, 2003). Large urban regions also have large labor markets with a rich variety of specialist competence structures and more interfirm job mobility, particularly among knowledge-intensive workers (Cohen and Levinthal, 1990; Almeida and Kogut, 1999; Andersson and Thulin, 2008).

Moretti (2004) suggests that plant productivity is an increasing function of external human capital in the local milieu, ${ }^{1}$ while Lychagin et al. (2010) find that geographical markets are very local, which is in line with Lamorgese and Ottaviano (2006) and others who recognize that spillovers rapidly fade with distance. Crespi et al. (2007) report that nearby suppliers and competitors (and customers to a lesser degree) are primary sources of external knowledge. They also find that much of this information is free, particularly that from competitors, but is not given freely, and that the presence of multinational firms makes these flows more intense. Goolsbee and Klenow (2002) report that larger regions and cities may have a greater availability of complementary services that reduce the costs of adopting and implementing complex technologies.

Cluster milieus are an agglomeration phenomenon that can develop in small and medium-sized urban regions, sharing the same spillover mechanisms as those attributed to metropolitan areas but limited to particular technologies or industries. Capello (2002) argues that clustering can be considered a general phenomenon in the modern economy and that a metropolitan region can be viewed as a cluster of clusters.

As emphasized by the theory of agglomeration economies, a metropolitan region offers a firm both accessibility to local and regional knowledge sources and greater opportunities to access global knowledge sources than other regions provide. The corresponding benefits from this metropolitan diversity of novelties and flows of ideas are often classified as Jacobs externalities or urbanization economies (Jacobs 1969, 1984).

Previous studies conclude that knowledge flows and spillovers are not only spatially bounded but also restricted to firms with the internal capacity to adopt ideas from outside sources. This type of capacity is reflected in each firm's innovation strategy, with firms classified into three categories: persistent innovators, occasional innovators and non-innovators.

In most fields of technology, progress is cumulative in nature, where experiences from current failures and successes are transformed into tomorrow's learning routines and knowledge stock. Because of this, a persistent innovator can draw from a larger number of earlier discoveries and advances than occasional or non-innovator firms. A persistent innovator firm is also better able to learn from not only internal knowledge sources but also knowledge sources in the surrounding environment (Cohen and Levinthal, 1990; Attewell, 1992; Åstebro, 2002).

The present paper adds to the literature by estimating and comparing internal and external factors influencing productivity by observing firms with three different innovation strategies located in four different categories of geographical areas.

\footnotetext{
${ }^{1}$ For Sweden, in 2007, more than 28 per cent of labor in the Stockholm region was knowledge-intensive. The share was 24 per cent and 23 per cent for the other two metropolitan regions Gothenburg and Malmö, respectively. The average share of knowledge intense labor was 18 per cent for medium-sized regions and 15 per cent for smaller regions.
} 


\section{Data and Descriptive Statistics}

We base our econometric analysis on observations from a set of manufacturing and service firms in Sweden with 10 or more employees from a representative sample from the CIS IV. The survey we use took place in 2005 and covered the 2002-2004 period. The rate of response was close to 70 per cent. The original sample contains 3,094 firms, and to obtain the full data set, we have merged the survey data with information from a database containing information about all firms in Sweden including human capital, measured as the number of employees with at least three years of university education, physical capital, value added, total assets and corporate ownership over a 10-year period. The matching process resulted in an unbalanced data set with 2,600-2,895 firms observed over the 1997-2006 period. The total number of observations over the 10-year period considered here is 25,892 .

The only information used from the CIS-survey is the firms' self-declared R\&D engagement. The R\&D efforts can be grouped into three categories: no, occasionally and persistent efforts. As we do not have data on innovation strategy for the whole period, we assume that the 2002-2004 behavior reflects the firms' long-run strategy. This is supported by the literature, which suggests that firms' R\&D investments vary less than most investments over the business cycle (Aghion et al., 2008), and that a firms innovation strategy typically is a long-term commitment (Klette and Kortum, 2004). In their investigation of Swedish data, Lööf et al. (2012) find that the relative performance of non-R\&D, occasional $R \& D$ and persistent R\&D firms remains invariant over a long period of time.

However, to avoid strong assumptions on the endurance firms R\&D, we limit the analysis to the period 2001-2006. The register information for the observed firms over the period 1997-2000 is exploited to create a lag structure and build instruments in the applied dynamic general method of moments (GMM) model (Arellano-Bond). This implies that the numbers of observations range between 14,823 and 10,143 depending on which regions are included in the regressions.

The monetary terms in the data are deflated by the Swedish Consumer Price Index. To reduce the influence of possible errors in our data, we have transformed all observations below the 1st percentile to be equal to the 1st percentile and applied the corresponding procedure for observations above the 99th percentile. This censoring procedure also reduces possible problem with our productivity measure: value added over ordinary employees. If a firm has a very small fraction ordinary workers, the productivity level can be extremely high.

Table 1 presents summary statistics for all firms and for firms separated according to their long-run R\&D strategy reported to the Innovation Survey. The upper part shows that 59 per cent of the firms in this study that do not conduct any R\&D activities (R1), whereas 17 per cent of the firms report occasional R\&D (R2) and 24 per cent are persistent innovators as reflected by recurrent $R \& D$ efforts year after year $(R 3)$.

In this analysis, we distinguish among four definitions of metropolitan area: metropolitan region (Stockholm, Gothenburg and Malmö), the largest metropolitan region (Stockholm), a metropolitan city (the cities of the three metropolitan regions) and the largest metropolitan city (the city of the largest metropolitan region). Sweden's three metropolitan regions all feature integrated labor markets. The table summarizes the different definitions of metropolitan areas used in the paper, where M1 represents the three metro regions (39 per cent of the Swedish firms observed), M2 is specific to the largest metro region (21 per cent of 
Table 1. Summary statistics over the 1997-2006 period

\begin{tabular}{|c|c|c|c|c|c|c|c|c|c|}
\hline & & \multicolumn{2}{|c|}{$\begin{array}{c}\text { All firms: } \\
100 \%\end{array}$} & \multicolumn{2}{|c|}{ R1 59\% } & \multicolumn{2}{|c|}{ R2 17\% } & \multicolumn{2}{|c|}{ R3 24\% } \\
\hline & & Mean & SD & Mean & SD & Mean & SD & Mean & SD \\
\hline \multicolumn{10}{|c|}{ Observations, fraction } \\
\hline \multicolumn{2}{|c|}{$\mathrm{M} 1_{\text {it }}$} & 0.39 & $(0.49)$ & 0.40 & $(0.49)$ & 0.33 & $(0.47)$ & 0.40 & $(0.49)$ \\
\hline \multicolumn{2}{|c|}{$\mathrm{M} 2_{i t}$} & 0.21 & $(0.40)$ & 0.21 & $(0.41)$ & 0.17 & $(0.38)$ & 0.21 & $(0.40)$ \\
\hline \multicolumn{2}{|l|}{$M 3_{t}$} & 0.22 & $(0.41)$ & 0.23 & $(0.42)$ & 0.16 & $(0.37)$ & 0.22 & $(0.41)$ \\
\hline \multicolumn{2}{|c|}{$M 4_{i t}$} & 0.12 & $(0.32)$ & 0.13 & $(0.33)$ & 0.10 & $(0.30)$ & 0.12 & $(0.32)$ \\
\hline \multicolumn{10}{|c|}{ Production and production factors } \\
\hline$y$ & Labor productivity $(\log )^{\mathrm{E}}$ & 6.18 & $(0.48)$ & 6.14 & $(0.47)$ & 6.17 & $(0.46)$ & 6.30 & $(0.49)$ \\
\hline \multirow[t]{2}{*}{$H$} & Skilled labor (log) & 0.36 & $(2.29)$ & -0.18 & $(2.13)$ & 0.25 & $(2.04)$ & 1.77 & $(2.26)$ \\
\hline & Skilled/total employment & 0.11 & $(0.16)$ & 0.08 & $(0.14)$ & 0.10 & $(0.16)$ & 0.17 & $(0.20)$ \\
\hline K & Physical capital (log) & 7.78 & $(2.88)$ & 7.40 & $(2.80)$ & 7.72 & $(2.73)$ & 8.77 & $(2.97)$ \\
\hline$L$ & Ordinary labor (log) & 3.40 & $(1.59)$ & 3.17 & $(1.44)$ & 3.34 & $(1.47)$ & 4.04 & $(1.84)$ \\
\hline \multicolumn{10}{|c|}{ Corporate ownership } \\
\hline O1 & Domestic nonaffiliate firms & 0.33 & & 0.40 & & 0.35 & & 0.32 & \\
\hline $\mathrm{O} 2$ & Domestic uninational firms & 0.30 & & 0.34 & & 0.25 & & 0.33 & \\
\hline $\mathrm{O} 3$ & Domestic multinationals & 0.20 & & 0.14 & & 0.17 & & 0.21 & \\
\hline $\mathrm{O} 4$ & Foreign multinationals & 0.17 & & 0.12 & & 0.22 & & 0.14 & \\
\hline \multicolumn{10}{|c|}{ Sector classification } \\
\hline S1 & High-technology manufacturing & 0.06 & & 0.04 & & 0.04 & & 0.06 & \\
\hline S2 & High-technology medium manufacturing & 0.16 & & 0.13 & & 0.06 & & 0.21 & \\
\hline S3 & Low-technology medium manufacturing & 0.15 & & 0.16 & & 0.06 & & 0.24 & \\
\hline S4 & Low-technology manufacturing & 0.23 & & 0.25 & & 0.18 & & 0.27 & \\
\hline S5 & Knowledge-intensive services & 0.17 & & 0.12 & & 0.31 & & 0.08 & \\
\hline S6 & Other services & 0.24 & & 0.30 & & 0.35 & & 0.14 & \\
\hline
\end{tabular}

Notes: M1: The three metro regions: Stockholm, Gothenburg and Malmo. M2: The largest metro region: Stockholm. M3: The three metro cities: Stockholm, Gothenburg and Malmo. M4: The largest metro city: Stockholm. R1: Firms with no R\&D. R2: Firms with occasional R\&D. R3: Firms with persistent R\&D. Mean and overall standard deviation reported. The estimations are based on 25,892 observations over the period 2001-2006, but in order to create lagged variables and build instruments, we use observations for the period 1997-2006.

the firms), M3 includes the cities Stockholm, Gotenburg and Malmö (22 per cent of the firms) and M4 is only the city of Stockholm (12 per cent of the firms). No systematic pattern in R\&D strategy with respect to a firm's location can be identified across the columns.

The middle section of Table 1 reports descriptive statistics for the dependent variable, labor productivity and five regressors that we will treat as endogenous or predetermined in the regression analysis. These regressors are skills, expressed as the (log) number of employees with at least three years of university education; the (log) physical capital capturing total physical assets; and (log) ordinary labor, defined as labor other than skilled labor. Substantial differences are observed between firms with persistent R\&D efforts and other firms. Firms with persistent R\&D have a greater intensity of both human capital and 
physical capital, and their labor productivity is superior to that of firms without persistent R\&D efforts.

The bottom part of Table 1 presents statistics for two categories of exogenous control variables. Regarding the corporate ownership structure, the results show that non-MNE firms are overrepresented among non-R\&D firms, while foreign-owned MNEs are underrepresented among firms conducting R\&D annually. The proportion of medium technology manufacturing firms is higher within the persistent R\&D group compared to the proportion among all firms.

Table 2 introduces the structure for our empirical analysis and for the estimates reported in Table 4. The focus here is pair-wise correlation with labor productivity, and rows $1-5$ report results for five composite variables combing location (M) and R\&D strategy (R). The reference is firms located in nonmetro regions that are not engaged in $R \& D$ activities (MR1). This group of firms is compared with metropolitan firms with no R\&D (MR2), nonmetro firms with occasional R\&D (MR3), metro firms with occasional R\&D (MR4), nonmetro firms with persistent R\&D (MR5) and metro firms persistently conducting R\&D (MR6). Thus, the horizontal dimension of the table investigates the relationship between productivity and R\&D strategy on the one hand and between productivity and metropolitan versus nonmetropolitan location on the other hand.

The vertical dimension of the table adds the aspect of possible differences between different categories of metropolitan areas. In particular, we are interested in potential divergences between metropolitan regions and metropolitan cities. The vertical dimension also investigates whether the high knowledge intensity that distinguishes Stockholm from the other

Table 2. Pair-wise correlation with labor productivity for four different metropolitan areas 2001-2006

\begin{tabular}{|c|c|c|c|c|}
\hline & \multicolumn{4}{|c|}{ Metro is measured as } \\
\hline & $\begin{array}{c}\text { M1: Three } \\
\text { metro regions }\end{array}$ & $\begin{array}{l}\text { M2: Largest } \\
\text { metro region }\end{array}$ & $\begin{array}{l}\text { M3: Three } \\
\text { metro cities }\end{array}$ & $\begin{array}{c}\text { M4: Largest } \\
\text { metro city }\end{array}$ \\
\hline MR1 & 0.00 & 0.00 & 0.00 & 0.00 \\
\hline MR2 & 0.02 & 0.06 & 0.01 & 0.06 \\
\hline MR3 & -0.01 & 0.00 & -0.01 & -0.01 \\
\hline MR4 & 0.04 & 0.05 & 0.04 & 0.06 \\
\hline MR5 & 0.01 & 0.03 & 0.02 & 0.02 \\
\hline MR6 & 0.08 & 0.10 & 0.09 & 0.10 \\
\hline H: skilled labor (log) & 0.53 & 0.53 & 0.53 & 0.51 \\
\hline K: physical capital (log) & 0.43 & 0.42 & 0.44 & 0.44 \\
\hline$L:$ ordinary labor (log) & -0.60 & -0.59 & -0.61 & -0.59 \\
\hline
\end{tabular}

Notes: M1: The three metro regions: Stockholm, Gothenburg and Malmo. M2: The largest metro region: Stockholm. M3: The three metro cities: Stockholm, Gothenburg and Malmo. M4: The largest metro city: Stockholm. MR1 is firms with no $R \& D$ and located in a nonmetro area. MR1 is reference category for MR2-MR6. MR2 is firms with no R\&D and located in a metro area. MR3 is firms with occasional R\&D and located in a nonmetro area. MR4 is firms with occasional R\&D and located in a metro area. MR5 is firms with persistent R\&D and located in a nonmetro area. MR6 is firms with persistent $R \& D$ and located in a metro area. Labor productivity is expressed as value added per ordinary labor. 
two Swedish metropolitan areas (number of research universities, the level of education, knowledge-intensive business firms, the total amount of R\&D investments) constitutes an additional advantage for innovation activities. In the table, the three metropolitan regions as a group are referred to as M1, the Stockholm region is referred to as M2, the three metropolitan cities as a group are referred to as M3 and the city of Stockholm is referred to as M4.

Table 2 also presents correlation coefficients for the covariates human capital, physical capital, firm size, export intensity and access to equity capital. Both skilled labor and physical capital are closely related to labor productivity.

The year-to-year transition matrix in Table 3 reveals that firms tend to remain in the same location over the whole 10-year period considered here. No differences are observed in the tendency to move with respect to R\&D strategy. The exception is that R\&D firms exhibit a small tendency to move from nonmetro regions to metropolitan areas (see Table 3 ).

\section{Methodology and Empirical Strategy}

\subsection{General Framework}

Our empirical model is a modified firm-level Cobb-Douglas production function for firm $i$, with capital, labor and skills included as inputs. The variable that we would like to explain is labor productivity, and our key aim is to determine the effects of internal knowledge accumulation created by a particular R\&D strategy and external knowledge spillovers from the local milieu. We use the long-run R\&D strategy $(R)$ of a firm as a proxy for its internal knowledge process and the location in a Metropolitan area $(M)$ as an indicator that the firm can benefit from a local milieu characterized by advantageous knowledge sources. Our general model is set up as follows:

$$
Y=A \cdot K^{\beta_{1}} \cdot L^{\beta_{2}} \cdot H^{\beta_{3}}
$$

where $Y_{i t}$ is value added, $A_{i t}$ is the technology shifter, $K_{i t}$ is the firm's capital stock, $L_{i t}$ is the number of ordinary laborers and $H_{i t}$ is a skill indicator measuring the number of employees

Table 3. Year-to-year persistence in the same classification

\begin{tabular}{|c|c|c|c|}
\hline Variable & Definition & $0 / 0$ & $1 / 1$ \\
\hline $\mathrm{MR} 1_{i t}$ & Nonmetro $\times$ non-R\&D & 99.65 & 99.40 \\
\hline $\mathrm{MR}_{i t}$ & Metro $\times$ non-R\&D & 99.68 & 99.53 \\
\hline $\mathrm{MR}_{i t}$ & Nonmetro $\times$ occasional R\&D & 99.90 & 99.40 \\
\hline $\mathrm{MR}_{i t}$ & Metro $\times$ occasional R\&D & 99.91 & 97.22 \\
\hline $\mathrm{MR}_{i t}$ & Nonmetro $\times$ persistent $R \& D$ & 99.82 & 99.17 \\
\hline $\mathrm{MR}_{i t}$ & Metro $\times$ persistent $R \& D$ & 99.84 & 97.12 \\
\hline
\end{tabular}

Notes: 0/0: The proportion of firms that did not belong to this group in one year that also did not belong to this group the next year. 1/1: The proportion of firms that belonged to this group in one year that also belonged to this group the next year. MR1 is firms with no R\&D and located in a nonmetro area. MR2 is firms with no R\&D and located in a metro area. $M R 3$ is firms with occasional R\&D and located in a nonmetro area. MR4 is firms with occasional R\&D and located in a metro area. MR5 is firms with persistent R\&D and located in a nonmetro area. MR6 is firms with persistent R\&D and located in a metro area. 
with at least three years of university education. The ordinary labor variable $L$ is assumed to reflect size.

Expressing value added in per ordinary employee $(Y / L)$, we obtain the following expression:

$$
y=\frac{Y}{L}=\frac{A K^{\beta_{1}} L^{\beta_{2}} H^{\beta_{3}}}{L}=A K^{\beta_{1} L^{\beta_{2-1}} H^{\beta_{3}}}
$$

The log transformation of the productivity Equation 2 is then:

$$
\ln y=\ln A+\beta_{1} \ln K_{i t}+\left(\beta_{2}-1\right) \ln L+\ln \beta_{3} H .
$$

We estimate $\hat{\beta}=\left(\beta_{2}-1\right)$, which will come out as negative for $\beta_{2}<1$.

We incorporate the location of each firm and its $R \& D$ strategy into this framework through the shift factor in the production function in the following way:

$$
A_{i t}=A_{0}+\alpha_{1} R M_{i t}
$$

where $R M$ is a composite variable that for each firm is represented by one of the category indicators MR1, .., MR6, and where there is one $\alpha_{1}$ parameter for each indicator. An indicator informs us whether a firm is located in a metropolitan area and which type of R\&D strategy the firm employs.

Adding a dynamic component, ownership $(O)$, sector classification $(S)$ and time $(Z)$ to Equation 3, employing the composite variable RM in Equation 4, including an error term and allowing for a lag structure of the regressors, we can express the Equation (in logs) as:

$$
\begin{gathered}
y_{i t}=A_{0}+\alpha_{1} R M_{i t}+\gamma_{1} y_{i, t-p}+\beta_{1} K_{i, t-q}+\left(\beta_{2}-1\right) L_{i, t-q}+\beta_{3} H_{i, t-q}+\lambda_{1} O_{i t}+\lambda_{2} S_{i t}+\lambda_{3} Z_{t}+\varepsilon_{i t} \\
p=1,2,3,4 \\
q=0,1 \\
\varepsilon_{i t}=\eta_{i}+\nu_{i t},
\end{gathered}
$$

where $\eta_{i}$ is unobserved firm heterogeneity and $\nu_{i t}$ is the idiosyncratic component of the error term.

\subsection{Endogenous and Exogenous Variables}

Among several possible estimators, we are using a dynamic GMM estimator system (Arellano and Bover, 1995; Blundell and Bond, 1998). The main motivation for choosing this ArellanoBond-type estimators is that it designed for dealing with situations similar to our framework: (1) few time periods and many individuals, (2) a linear functional relationship, (3) a single lefthand-side variable that is dynamic, depending on its own past realizations, (4) independent variables that are not strictly exogenous, (5) fixed individual effects and (6) heteroskedasticity and autocorrelation within individuals, but not across them (Roodman, 2009).

The particular dynamic model we employ when estimating the combined impact of R\&D strategy and location on firm performance is a one-step GMM estimator system. To apply 
Equation 5 to this framework, we need to specify the variables as endogenous, predetermined, weakly exogenous and strictly exogenous.

Based on the literature, we will treat the controls $y, K, L$ and $H$ as endogenous, predetermined or weakly exogenous regressors. Regarding the endogeneity issue, we assume that the R\&D strategy, choice of location and thus the interaction variable $M R$ are exogenous in the system, approaching together with corporate ownership structure, sector classification and year dummies. The motivation for the exogeneity assumption of MR is that the instruments in the GMM matrix are deeper lags of the endogenous variables, and no such meaningful lag can be found for the almost time-invariant MR regressors.

Will the exogeneity assumption about R\&D strategy and location yield biased estimates? Lööf and Heshmati (2006) and Mairesse and Mohnen (2010) investigate the importance of instrumenting innovation expenditures in structural models using crosssectional data. The results are consistent between studies and show that the estimated correlation between productivity and innovation expenditures is almost the same whether or not the latter is treated as endogenous. Consider that location decisions occur with low frequency so that location remains a historically given fact along a sequence of dates. In that case, location can be assumed to change on a slow time scale, which means that it can be treated as exogenous in the analysis. The interaction variable $M R$, which then can take on six different values, is extremely persistent from year to year. Between 97 per cent and 99 per cent of all firms that belonged to any one of these six groups in one year also belonged to the same group in the following years (Table 3 ).

There are three categories of innovation strategy $(\mathrm{R} 1, \mathrm{R} 2, \mathrm{R} 3)$ and two types of location (nonmetropolitan, NM, and metropolitan, M). Is there any statistical co-variation in the pattern of historically given combinations of strategy type and location type? Can we instead think of strategy and location as orthogonal? The latter seems to be the case, verified by the fact that the number of firms that apply a given strategy in NM and $\mathrm{M}$ is proportional to the total number of firms in NM and M. As Table 1 shows, the share of persistent innovators in the three metropolitan regions is 40 per cent. The total number of non-innovators in the same regions is also 40 per cent. Thus, there is no sign of bias in how firms in the past have chosen their location and strategy.

\section{Results}

The results are presented in Table 4 which is organized in four columns, M1-M4. In each of the four columns, a particular metro definition is compared with exactly the same reference group, which consists of all locations in Sweden outside the three metropolitan regions.

In Column M1, metro region locations (Stockholm, Gothenburg and Malmö) are compared with the nonmetro region locations. This comparison involves 14,823 observations. Column M2 compares labor productivity for a typical firm in the Stockholm region with firms in nonmetropolitan areas. To disentangle the specific metro effect for the Stockholm region, firms located in the Gothenburg and Malmö regions are excluded from this regression $(11,567$ observations). Column M3 estimates the impact of metro city externalities (Stockholm, Gothenburg and Malmö) with the reference. This analysis includes 11,589 observations. Finally, column M4 presents the corresponding estimates for Stockholm city versus nonmetropolitan areas, with firms in the rest of the Stockholm region, and regions Gothenburg and Malmö excluded. The number of observations for this comparison is 10,143 . 
Table 4. Dependent variable is log value added per ordinary employee $(y)$. Winsorizing data: 0.01 .

\begin{tabular}{|c|c|c|c|c|}
\hline & $\begin{array}{c}\text { M1: Three } \\
\text { metro regions }\end{array}$ & $\begin{array}{l}\text { M2: Largest } \\
\text { metro region }\end{array}$ & $\begin{array}{l}\text { M3: Three } \\
\text { metro cities }\end{array}$ & $\begin{array}{l}\text { M4: Largest } \\
\text { metro city }\end{array}$ \\
\hline MR1 & Reference & Reference & Reference & Reference \\
\hline MR2 & $\begin{array}{c}0.002 \\
(0.011)\end{array}$ & $\begin{array}{c}0.019 \\
(0.016)\end{array}$ & $\begin{array}{r}-0.000 \\
(0.016)\end{array}$ & $\begin{array}{c}0.026 \\
(0.021)\end{array}$ \\
\hline MR3 & $\begin{array}{c}0.017 \\
(0.011)\end{array}$ & $\begin{array}{c}0.013 \\
(0.011)\end{array}$ & $\begin{array}{c}0.013 \\
(0.011)\end{array}$ & $\begin{array}{c}0.013 \\
(0.011)\end{array}$ \\
\hline MR4 & $\begin{array}{c}0.020 \\
(0.021)\end{array}$ & $\begin{array}{c}0.024 \\
(0.029)\end{array}$ & $\begin{array}{c}0.026 \\
(0.029)\end{array}$ & $\begin{array}{c}0.027 \\
(0.039)\end{array}$ \\
\hline MR5 & $\begin{array}{l}0.076^{\star * *} \\
(0.024)\end{array}$ & $\begin{array}{l}0.069^{\star * *} \\
(0.025)\end{array}$ & $\begin{array}{l}0.074^{\star \star \star} \\
(0.025)\end{array}$ & $\begin{array}{l}0.062^{\star \star} \\
(0.026)\end{array}$ \\
\hline MR6 & $\begin{array}{l}0.097^{\star \star \star} \\
(0.030)\end{array}$ & $\begin{array}{l}0.098^{\star *} \\
(0.039)\end{array}$ & $\begin{array}{l}0.125^{\star \star \star} \\
(0.041)\end{array}$ & $\begin{array}{l}0.133^{\star \star} \\
(0.058)\end{array}$ \\
\hline \multicolumn{5}{|l|}{ Controls } \\
\hline$y_{t-1}$ & $\begin{array}{l}0.660^{\star \star \star} \\
(0.064)\end{array}$ & $\begin{array}{l}0.690^{\star \star \star} \\
(0.068)\end{array}$ & $\begin{array}{l}0.698^{\star \star \star} \\
(0.066)\end{array}$ & $\begin{array}{l}0.657^{\star \star \star} \\
(0.074)\end{array}$ \\
\hline$H$ & $\begin{array}{c}0.066^{*} \\
(0.040)\end{array}$ & $\begin{array}{l}0.094^{\star *} \\
(0.041)\end{array}$ & $\begin{array}{c}0.083^{* *} \\
(0.037)\end{array}$ & $\begin{array}{l}0.101^{* * *} \\
(0.037)\end{array}$ \\
\hline$K$ & $\begin{array}{c}0.029 \\
(0.018)\end{array}$ & $\begin{array}{c}0.018 \\
(0.018)\end{array}$ & $\begin{array}{c}0.018 \\
(0.015)\end{array}$ & $\begin{array}{l}0.028^{*} \\
(0.016)\end{array}$ \\
\hline$L$ & $\begin{array}{c}-0.236^{\star \star \star} \\
(0.049)\end{array}$ & $\begin{array}{c}-0.253^{\star * *} \\
(0.048)\end{array}$ & $\begin{array}{c}-0.294^{\star \star \star} \\
(0.046)\end{array}$ & $\begin{array}{c}-0.302^{\star \star *} \\
(0.047)\end{array}$ \\
\hline Equality of mean & & & & \\
\hline $\mathrm{MR6}=\mathrm{MR} 5$ & 0.235 & 0.248 & $0.040^{* *}$ & $0.070^{\star}$ \\
\hline $\mathrm{MR} 6=\mathrm{MR} 4$ & $0.017^{\star \star}$ & $0.023^{\star \star}$ & $0.002^{\star \star \star}$ & $0.026^{\star \star}$ \\
\hline $\mathrm{MR6}=\mathrm{MR} 3$ & $0.001^{\star * *}$ & $0.016^{\star \star \star}$ & $0.000^{\star \star \star}$ & $0.026^{\star \star}$ \\
\hline $\mathrm{MR6}=\mathrm{MR} 2$ & $0.000^{\star \star \star}$ & $0.016^{\star \star \star}$ & $0.000^{\star \star \star}$ & $0.032^{\star *}$ \\
\hline $\mathrm{MR5}=\mathrm{MR} 4$ & $0.018^{\star *}$ & 0.129 & $0.073^{*}$ & 0.314 \\
\hline $\mathrm{MR5}=\mathrm{MR} 3$ & $0.000^{\star \star \star}$ & $0.010^{\star *}$ & $0.000^{\star \star \star}$ & $0.029^{\star \star}$ \\
\hline $\mathrm{MR5}=\mathrm{MR} 2$ & $0.002^{\star * *}$ & $0.028^{\star *}$ & $0.000^{\star \star \star}$ & 0.145 \\
\hline Observations & 14,823 & 11,576 & 11,589 & 10,143 \\
\hline AR (2) & 0.115 & 0.376 & 0.135 & 0.801 \\
\hline Instruments, no & 149 & 149 & 149 & 149 \\
\hline Hansen overid & 0.066 & 0.321 & 0.548 & 0.405 \\
\hline
\end{tabular}

Notes: Interpretation of the interaction variables MRi: $100 \times\left(e^{\mathrm{MR} i}-1\right) \%$. M1: The three metro regions: Stockholm, Gothenburg and Malmo. M2: The largest metro region: Stockholm. M3: The three metro cities: Stockholm, Gothenburg and Malmo. M4: The largest metro city: Stockholm. MR1 is firms with no R\&D and located in a nonmetro area. MR1 is reference category for MR2-MR6. MR2 is firms with no R\&D and located in a metro area. MR3 is firms with occasional $R \& D$ and located in a nonmetro area. MR4 is firms with occasional R\&D and located in a metro area. MR5 is firms with persistent $R \& D$ and located in a nonmetro area. MR6 is firms with persistent R\&D and located in a metro area.

${ }^{\star}$ Significant at $10 \%,{ }^{* *}$ significant at $5 \%,{ }^{* *}$ significant at $1 \%$. Windmeijer corrected standard errors are presented in parentheses.

${ }^{a}$ Wald test, prob $>\chi^{2}$, null hypothesis is that the means are equal. 
The upper part of Table 4 presents results for the six key variables that combine R\&D strategy and location, which are labeled $M R 1-M R 6$. The reference group is nonmetro and non-R\&D firms (MR1). MR2 estimates the productivity for non-R\&D firms if they are located in a metro area. The variables in rows MR3 and MR4 report the corresponding coefficients for firms with occasional R\&D. Rows MR5 and MR6 show regression results for persistent R\&D firms located in nonmetro and metro areas, respectively.

The middle section of the table shows coefficient estimates for selected covariates. In the bottom part of the table, two categories of test statistics are reported. The first is a Wald test investigating the equality of means. The second reports whether the serial correlation in the error term (AR (2)) was successfully eliminated and clarifies the validity of the instruments in our model specification (Hansen).

\subsection{Empirical Analysis}

Table 4 estimates the importance of metropolitan externalities on firm productivity expressed in real prices, showing that persistent innovators are a distinct category of firms in terms of productivity and that the productivity premium of their innovation strategy increases with location in a dense area. Conducting R\&D on an occasional basis only influences productivity marginally and not statistically different from firms with no R\&D efforts. The results suggest that only persistent R\&D-firms are able to exploit the greater opportunities available in metropolitan areas.

Considering the dynamic GMM estimates in detail, the four columns M1-M4 reject the assumption that metropolitan regions provide leverage effects for all firms. The results for non-R\&D firms (MR2) in the three largest metro regions and in the largest metro region are not significantly different from identical firms located in nonmetro regions. Only the largest metro region (column M2) and the largest city (M4) offer conditions that can also be exploited by firms not engaged in R\&D. The size of the estimates (0.02) is in line with the results reported in a very recent literature survey (Klaesson et al., 2014), however not statistically significantly different from the reference alternative.

The MR3 and MR4 estimates in rows 3 and 4 compare the occasional R\&D firms with the reference group of non-R\&D businesses in nonmetro areas. Row 3 presents strong evidence that temporary engagements have no impact on long-run productivity. These results suggest that these activities might have been necessary to update the efficiency of the production process or the product quality. The alternative could be a decrease in the level of productivity. Similar, row 4 suggests that occasional R\&D efforts in metro areas are no indicator of a process of dynamic development that increases long-run productivity. The coefficient estimates are about 0.2 , but not even close to be significant. Thus, occasional $R \& D$ engagement, for instance, in the form of purchasing services from R\&D consultants, cannot be seen as opening the window to nearby knowledge in general. Our interpretation here is that the free, but not freely given, local knowledge (Crespi et al., 2007) requires substantial accessibility capacity to be grasped. Among the vast majority of non-temporary and $R \& D$ companies in metropolitan areas, this ability is weak.

Rows 5 and 6 present regression results for firms with persistent R\&D engagement. Across all four columns, we see that the estimates for persistent R\&D firms in nonmetro areas (row 5) are quite sizeable and significant. The annual productivity premium of being a persistent innovator is within a range of $6-8$ per cent across all regions. This implies that that 
the average persistent innovator can be considered as self-selected to superior performance wherever it is located. The MR6 estimate in column 1 reports that a metropolitan region location increases the productivity premium for a persistent innovator with about 2 per cent. Columns $2-4$ indicate that this premium increases with the density of the metro area. The average externality effect for persistent innovators is 3 per cent in the largest metropolitan region, 5 per cent in the three metro cities and 8 per cent in the largest metro city, everything else equal.

The controls of the dynamic regression presented in Table 4 are the lagged dependent variable, human capital, physical capital, firm size, sector and year. The level of productivity in the previous year is a good predictor for current productivity. GMM estimates shows that the marginal effect of human capital on productivity is $6-10$ per cent, depending of the model specification. The estimated effect is biggest in the largest city. The estimate of physical capital enters into the equation with a positive coefficient $(0.02-0.03)$, but only weakly significant or non-significant. In line with our discussion in Section 4 , the estimated size of ordinary labor coefficient $\left(\beta_{2}-1\right)$ is negative, while the regressions results suggest a positive association between firm size and labor productivity. In order to save space, the estimates for corporate ownership, sector classification and year dummies are not reported.

\subsection{Summarizing the Findings}

Summarizing the results from our most preferred model as reported in Table 4, the following facts emerge. First, persistent $R \& D$ firms in metro areas are significantly more productive than occasional R\&D firms and non-R\&D firms irrespective of location. With nonmetro and non- $R \& D$ as the reference, the premium for metro firms conducting persistent $R \& D$ is $10-14$ per cent depending on the definition of a metro area. This difference falls to 6-8 per cent when the persistent R\&D firm is located outside a metro region. Second, occasional R\&D efforts have no sustained effects on firms' productivity regardless of they are located in a metro area or not. Third, we find no evidence of metropolitan externalities for non-R\&D firms. Thus, it appears as if the internal knowledge that a firm achieves through persistent R\&D efforts is a critical feature for accession of external knowledge sources.

\section{Conclusions}

The presence of external knowledge flows should reveal itself in social return to investments in addition to the private returns. A long range of empirical studies has shown that the social rate of return differs across locations and that knowledge flows reduce in volume and intensity as the distance between origin and destination grows.

Our study contributes to this literature by showing that the particular innovation strategy of a firm is crucial for its ability to make use of a metropolitan milieu comprising knowledge flows and diversity of novel ideas. The systematic study of a large set of representative firms also generates new and unique estimates of the magnitude of the metropolitan effect. Glaeser and Gottlieb (2009) report that the income elasticity with respect to city size in the USA is 4-8 per cent. Income is closely correlated with firms' productivity, and we show that such effects can be explained by the combination of sustained internal innovation efforts and metropolitan externalities. 
This paper decomposes the national geography of firm location into nonmetropolitan areas on the one hand, and metropolitan areas on the other (metropolitan regions, the largest metropolitan region, metropolitan cities and the largest metropolitan city). In parallel, this study classifies the firms' long-run R\&D strategies into three distinct alternatives: no $R \& D$ efforts, occasional R\&D and persistent R\&D. The result indicates that metropolitan cities offer more innovation-relevant knowledge flows than other locations.

Applying a dynamic GMM estimator to Swedish firm-level observations over a six-year period, the following pattern emerges: without innovation efforts, the knowledge milieu of a metropolitan region provides no benefits, and a metropolitan city provides only limited and not statistically confirmed benefits for non-innovators. For nonmetropolitan locations, occasional R\&D efforts do not make a significant difference in productivity compared to what prevails for firms without any $R \& D$ efforts, and the effect of temporary R\&D is only marginally lager for firms located in a metropolitan area. Persistent innovators are a distinct firm category in each type of location, and the productivity premium of their innovation strategy increases with location in dense areas.

To what extent can we expect the findings in this study to be relevant for other countries? Four major comments may illuminate this question. First, none of the three metropolitan regions is very large. But they are different and represent a diverse sample: Stockholm has a well spread-out underground system for commuting, whereas Gothenburg and Malmö do not. A second difference is that Malmö is a close neighbor of Copenhagen metropolitan region in Denmark. Third, the Swedish industry sector composition matches what prevails in other OECD economies, which should favor international validity. Fourth, a distinguished feature of the Swedish economy is that both small and big firms tend to export a comparative large share of their output. In general we know that persistent exporters also tend to be persistent innovators, and this may imply that the Swedish firms are a bit idiosyncratic in international comparison.

\section{Acknowledgements}

We thank Zoltan Acs, John Cantwell, Jacques Mairesse, Pierre Mohnen and seminar participants at the WRSA meeting, Kauai, Hawaii, for helpful conversations and comments. Jeffry Furman and two anonymous referees provided especially insightful comments. Support for this research from VINNOVA is also gratefully acknowledged.

\section{References}

Aghion, P., Askenazy, P., Berman, N., Cette, G. and Eymard, L. (2008) Credit constraints and the cyclicality of R\&D investment: Evidence from France, Banque de France Working Paper 198.

Almeida, P. and Kogut, P. (1999) Localization of knowledge and the mobility of engineers in regional networks, Management Science, 45, pp. 905-917.

Andersson, M. and Thulin, P. (2008) Globalisering, arbetskraftens rörlighet och produktivitet [Globalisation, labour mobility and productivity] (Stockholm: Globaliseringsrådet).

Arellano, M. and Bover, O. (1995) Another look at instrumental variable estimation of error component models, Journal of Econometrics, 68 , pp. 29-51.

Åstebro, Thomas (2002) Noncapital investment costs and the adoption of CAD and CNC in U.S. metalworking industries, Rand Journal of Economics, 33(4), pp. 672-678. 
Attewell, P. (1992, February) Technology diffusion and organizational learning: The case of business computing, Organizational Science, 3, pp. 1-19.

Beckmann, M. J. (2000) Interurban knowledge networks, in: D. Batten (Ed.), Learning, Innovation and Urban Evolution, pp. 127-135 (London: Kluwer Academic).

Bloom, N., Schankerman, M. and van Reenen, J. (2013) Identifying technology spillovers and product market rivalry, Econometrica, 81(4), pp. 1347-1393.

Blundell, R. S. and Bond, S. (1998) Initial conditions and moment restrictions in dynamic panel data models, Journal of Econometrics, 87(1), pp. 115-143.

Capello, R. (2002) Entrepreneurship and spatial externalities. Theory and measurement, Annals of Regional Science, 36, pp. 387-402. Cohen, W. and Levinthal, D. (1989) Innovation and learning: The two faces of R\&D, The Economic Journal, 99, pp. 569-596.

Cohen, W. and Levinthal, D. (1990) Absorptive capacity: A new perspective on learning and innovation, Administrative Science Quarterly, 35(1), pp. $128-158$.

Crespi, G., Criscuolo, C., Haskel, J. and Slaughter, M. (2007) Productivity growth, knowledge flows and spillovers, CEP Discussion Papers dp0785.

Fujita, M. and Thisse, J.-F. (2002) Economics of Agglomeration. Cities, Industrial Location and Regional Growth (Cambridge: Cambridge University Press).

Glaeser, E. L. and Gottlieb, J. D. (2009) The wealth of cities: Agglomeration economies and spatial equilibrium in the United States, Journal of Economic Literature, American Economic Association, 47(4), pp. 983-1028.

Glaeser, E. L. and Mare, D. C. (2001) Cities and skills, Journal of Labor Economics, 19(2), pp. 316-342.

Goolsbee, A. and Klenow, P. J. (2002) Evidence on learning and network externalities in the diffusion of home computers, Journal of Law and Economics, 45(2), pp. 317-343.

Greenstone, M., Hornbeck, R. and Moretti, E. (2010) Identifying agglomeration spillovers: Evidence from winners and losers of large plant openings, Journal of Political Economy, 118(3), pp. 536-598.

Jacobs, J. (1969) The Economy of Cities (New York: Vintage).

Jacobs, J. (1984) Cities and the Wealth of Nations (New York: Random House).

Klaesson, J., Larsson, J. P. and Norman, T. (2014) Accessibility and market potential, in: Martin Andersson \& Charlie Karlsson (Eds), Handbook of Research Methods and Applications in Economic Geography (Cheltenham: Edward Elgar).

Klette, T. J. and Kortum, S. (2004) Innovating firms and aggregate innovation, Journal of Political Economy, 112, pp. 986-1018.

Lamorgese, A. R. and Ottaviano, G. (2006) Intercity interactions: Evidence from the US, Meeting Paper 667 Society for Economic Dynamics.

Lööf, H., Andersson, M., Johansson, B. and Karlsson, C. (2012) R\&D Strategy and Firm Performance What is the Long-Run Impact of Persistent R\&D? in: Martin Andersson, Börje Johansson, Charlie Karlsson \& Hans Lööf (Eds), Innovation and Growth - From R\&D Strategies of Innovating Firms to Economy-Wide Technological Change, pp. 182-207 (Oxford: Oxford University Press).

Lööf, H. and Heshmati, A. (2006) On the relationship between innovation and performance: A sensitivity analysis, Economics of Innovation and New Technology, 15(4-5), pp. 317-344.

Lychagin, S., Pinkse, J., Slade, M. E. and van Reenen, J. (2010) Spillovers in space: Does geography matter?, NBER Working Papers 16188, National Bureau of Economic Research.

Mairesse, J. and Mohnen, P. (2010) Using innovations surveys for econometric analysis, NBER Working Papers 15857, National Bureau of Economic Research.

Moretti, E. (2004) Workers' education, spillovers, and productivity: Evidence from plant-level production functions, The American Economic Review, 94, pp. 656-690.

Polanyi, M. (1966) The Tacit Dimension (New York: Doubleday \& Company).

Roodman, D. (2009) How to do xtabond2: An introduction to difference and system GMM in Stata, The Stata Journal, 9(1), pp. 86-136.

Simmie, J. (2003) Innovation and urban regions as national and international nodes for transfer and sharing of knowledge, Regional Studies, 37, pp. 607-620.

von Hippel, E. (1994) Sticky information and the locus of problem solving: Implications for innovation, Management Science, 40, pp. $429-439$. 